
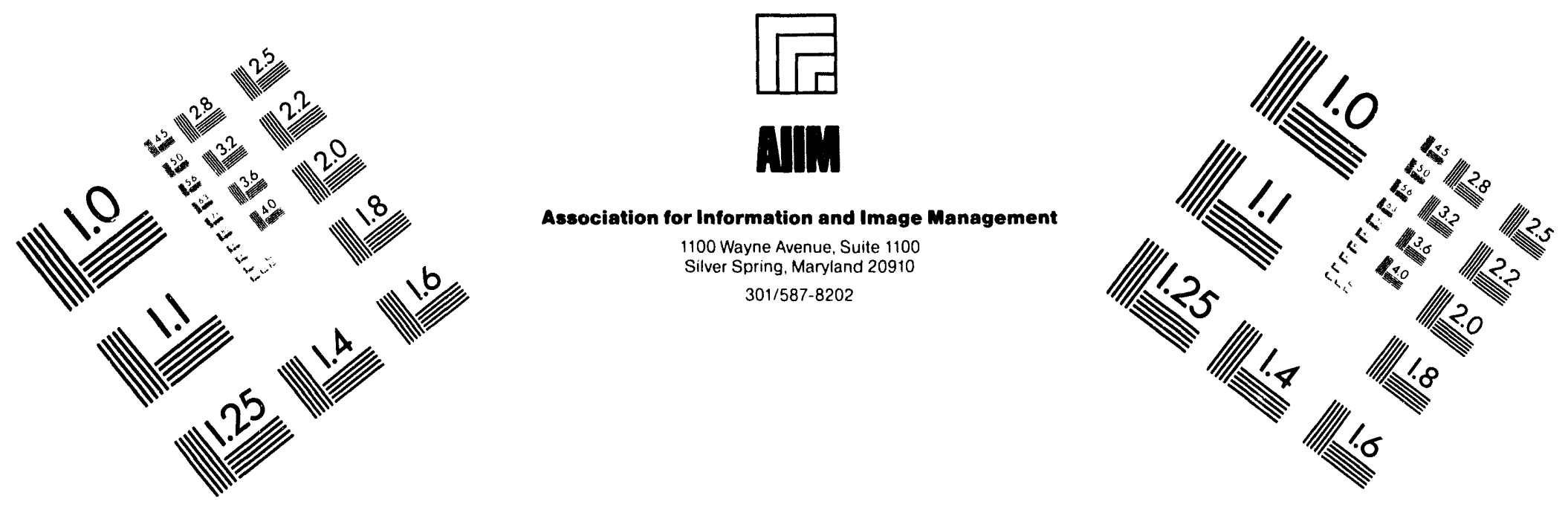

\title{
Centimeter
}

|

Inches
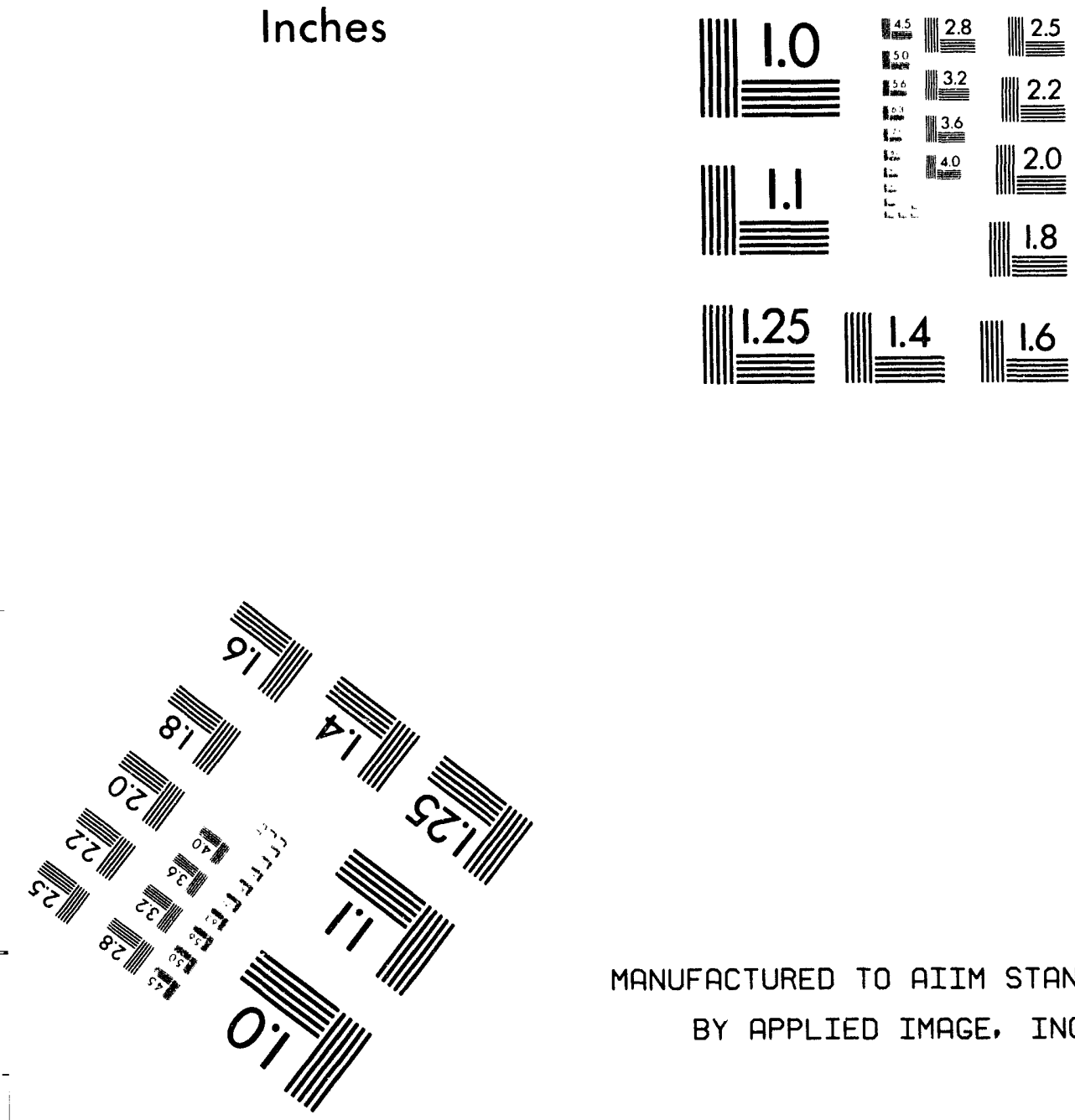

MANUFACTURED TO AIIM STANDARDS

BY APPLIED IMAGE, INC.

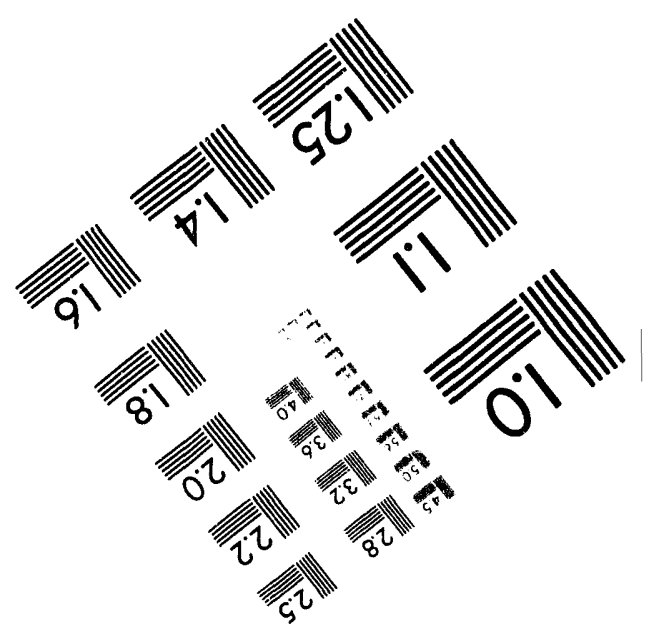



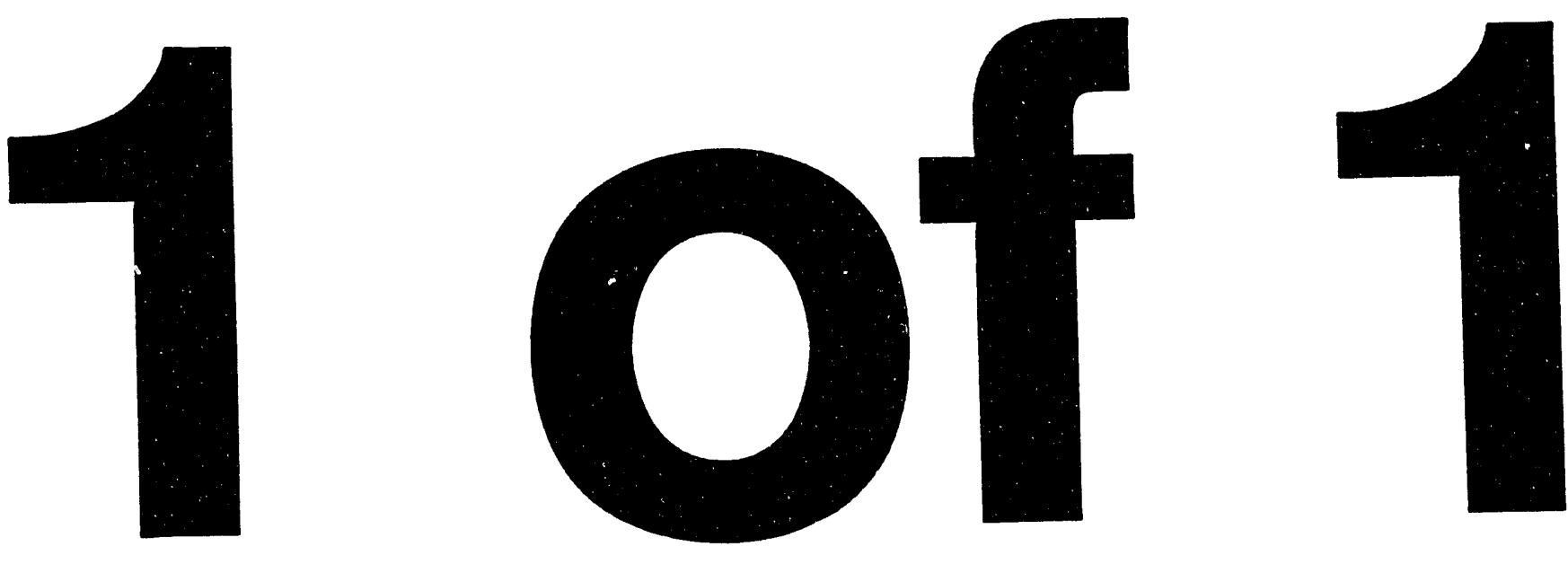
LBL-35475

UC-000

The Effect of Efficiency Standards on Water Use and Water Heating Energy Use in the U.S.: A Detailed End-use Treatment

Jonathan G. Koomey, Camilla Dunham, and James D. Lutz

Energy Analysis Program

Energy and Environment Division

Lawrence Berkeley Laboratory

Berkeley, CA 94720

May 1994

The work described in this paper was supported by the Office of Energy Efficiency and Alternative Fuels Policy, Office of Policy of the U.S. Department of Energy under Contract Number DE-AC03-76SF00098.

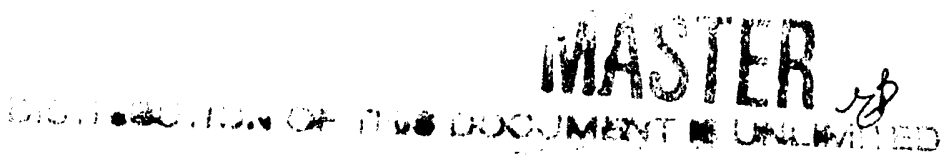




\section{The Effect of Efficiency Standards on Water Use and Water Heating Energy Use in the U.S.: A Detailed End-use Treatment ${ }^{1}$

\author{
Jonathan G. Koomey, Camilla Dunham, and James D. Lutz \\ Lawrence Berkeley Laboratory
}

\section{SYNOPSIS}

This paper analyzes US residential water use and water heater energy use. It also investigates water and energy savings associated with existing equipment efficiency standards.

Keywords: Residential codes and standards, Water heating, Water conservation, Forecasting, Program design

\section{ABSTRACT}

Water heating is an important end-use, accounting for roughly $16 \%$ of total primary energy consumption in the US residential sector. Recently enacted efficiency standards on water heaters and hot water-using equipment (e.g., dishwashers, clothes washers, showerheads, and faucets) will substantially aifect the energy use of water heaters in the future. Assessment of current and future utility programs and government policies requires that regulators, resource planners, and forecasters understand the effects of these regulations.

In order to quantify these impacts, this paper presents a detailed end-use breakdown of household hot and cold water use developed for the US Department of Energy. This breakdown is based on both previous studies and new data and analysis. It is implemented in a spreadsheet forecasting framework, which allows significant flexibility in specifying end-use demands and linkages between water heaters and hot water-using appliances.

We disaggregate total hot and cold water use (gallons per day) into their component parts: showers, baths, faucets (flow dominated and volume dominated), toilets, landscaping/other, dishwashers, and clotheswashers. We then use the end-use breakdown and data on equipment characteristics to assess the impacts of current efficiency standards on hot water use and water heater energy consumption.

\footnotetext{
${ }^{1}$ A shortened version of this report will be published in the proceedings to the 1994 ACEEE Summer Study Conference on Energy Use in Buildings.
} 


\section{SYNOPSIS}

\section{ABSTRACT}

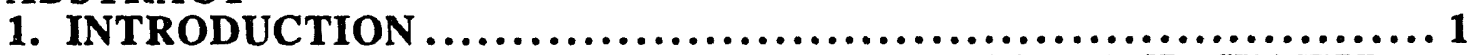

2. REVIEW OF CORE DATA ON WATER USE AND WATER

HEATING ENERGY USE $\ldots \ldots \ldots \ldots \ldots \ldots \ldots \ldots \ldots \ldots \ldots \ldots \ldots \ldots \ldots \ldots \ldots \ldots$

2.1 Characteristics of water heaters ........................................

2.2 Water temperature assumptions.....................................

2.3 Showers, sinks, and faucets .......................................

2.4 Toilets..................................................................6

2.5 Dishwashers and clotheswashers............................................6

2.6 Other uses ...........................................................

3. FORECASTING METHODOLOGY AND RESULTS $\ldots \ldots \ldots \ldots \ldots \ldots \ldots 6$

3.1 Forecasted number of households..................................6

3.2 Baseline and standards case forecasts: water use .....................9

3.3 Baseline and standards case forecasts: energy use ....................9

3.4 Energy savings...............................................

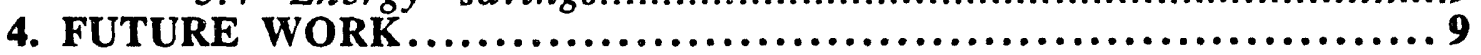

4.1 Sensitivity analysis/further disaggregation ...............................9

4.2 Energy losses in delivering water to the tap .........................13

4.3 Measurement of water use ..............................................13

4.4 Comparison to other forecasts .....................................13

4.5 "Upstream" and "Downstream" issues........................................13

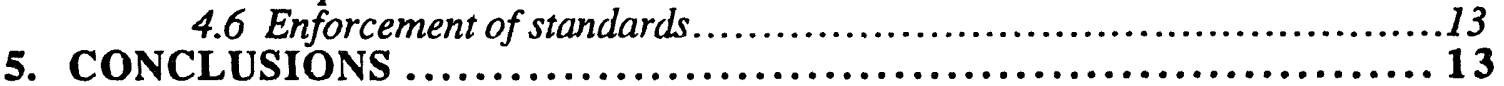

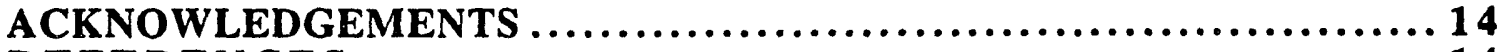

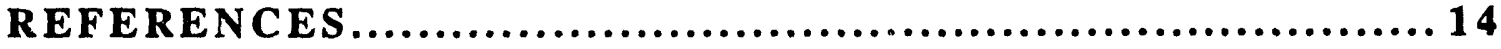




\section{INTRODUCTION}

The water heating end-use is perhaps the most complicated of all residential end-uses. Usage behavior varies greatly, and depends on ownership of other appliances (e.g., clothes washers and dishwashers), on the characteristics of those appliances and other water-using equipment, on water inlet temperatures, on hot water temperature set points, and on water use temperatures.

Water heating has generally been analyzed in a haphazard manner in the past, in large part because of its complexity. Measurement studies (with a few notable exceptions) have failed to capture the important data necessary for truly understanding how hot and cold water are used in US residences. For example, studies often report the number of gallons per day of hot water use per household, averaged over all households with different appliances. This number is only useful for determining total water heating energy use-it provides no guidance as to what impact different conservation measures might have on that usage. It is also of limited usefulness in assessing the energy use for water heating in a particular household. The only way to assess such issues is to disaggregate total hot water use to reflect the various components of hot water loads.

The guiding philosophy behind this paper is that explicit and well-chosen estimates about usage behavior for particular devices (e.g. the number of minutes each person showers per day) can be used to create a "bottom-up" estimate of total usage that is a reasonable portrayal of average water usage. Such detailed bottom-up estimates can be used to assess the effects of policies. In the case of water heating, creating such a disaggregated forecast is the only way to disentangle the effects of the various efficiency standards now affecting this end use. The "order of magnitude" character of the numbers is acceptable for most applications as long as they are derived in an internally consistent and complete manner, and as long as available data, basic physical principles, and common sense are used to guide the choice of parameters.

Characteristics of particular houses may be quite different from the usage assumptions shown here. Nevertheless, we believe that our first-order estimates crudely represent average water usage behavior in US residences. We eagerly await more detailed data on water usage from the many studies now being conducted by US utilities and others.

\section{REVIEW OF CORE DATA ON WATER USE AND WATER HEATING ENERGY USE}

\subsection{Characteristics of water heaters}

Table 1 shows the characteristics of residential water heaters of various vintages, derived from US DOE (1993). The relevant characteristics are energy factor (defined as energy delivered in the hot water at the tap, divided by total energy input), recovery efficiency (which is the efficiency of delivering heat to the water in the tank), and the standby losses (which are the constant losses associated with keeping the water in the tank hot and ready for use).

The energy factor, recovery efficiency, and standby losses are related using Equation (1):

$$
\mathrm{EF}=\frac{\text { Energy content of hot water delivered }}{\text { Total energy used to heat the water }}
$$


Table 1: Characteristics of water heaters

\begin{tabular}{|r|c|ccccc|}
\hline & Units & $\begin{array}{c}\text { Stock } \\
1990\end{array}$ & $\begin{array}{c}\text { Stock } \\
1993 \\
\text { w/1990 stds }\end{array}$ & $\begin{array}{c}\text { Sales } \\
\text { late 1980s }\end{array}$ & $\begin{array}{c}\text { Sales } \\
1990\end{array}$ & $\begin{array}{c}\text { Proposed Stds } \\
\text { 1-Jan-98 }\end{array}$ \\
\hline Energy Factors & & & & & & \\
Electricity & $\%$ & $82 \%$ & $83 \%$ & $84 \%$ & $88 \%$ & $189 \%$ \\
Gas & $\%$ & $49 \%$ & $50 \%$ & $49 \%$ & $54 \%$ & $57 \%$ \\
Oil & $\%$ & $46 \%$ & $46 \%$ & $47 \%$ & $51 \%$ & $67 \%$ \\
Standby losses & & & & & & \\
Electricity & Wh.th/hr & 97 & 89 & 86 & 57 & 10 \\
Electricity & Btus.th/hr (site) & 332 & 303 & 294 & 194 & 34 \\
Gas & Btus.th/hr & 1576 & 1453 & 1510 & 1125 & 948 \\
Oil & Btus.th/hr & 1576 & 1453 & 1510 & 1125 & 948 \\
Recovery efficiency & & & & & & \\
Electricity & $\%$ & $98 \%$ & $98 \%$ & $98 \%$ & $98 \%$ & $193 \%$ \\
Gas & $\%$ & $76 \%$ & $76 \%$ & $76 \%$ & $76 \%$ & $76 \%$ \\
Oil & $\%$ & $76 \%$ & $76 \%$ & $76 \%$ & $76 \%$ & $76 \%$ \\
\hline
\end{tabular}

(1) Standby losses and recovery efficiency for gas and electric water heaters (WHs) derived from US DOE (1993). Oil water heaters assumed to be the same as gas.

(2) Energy factors (EFs) for stock (1990 and 1993) and late 1980s sales derived from historical shipments taken from Hanford et al. 1994. EFs for 1990 sales equal the 1990 standards.

Proposed 1998 standard on electric WHs requires manufacturers to produce only heat pump water heaters.

Recovery efficiency for heat pump water heaters varies depending on water temperatures.

Recovery efficiency shown here is an overall average.

(3) (Standby losses + the heat content of water used)/recovery efficiency $=$ total WH energy use.

Energy factor $=$ the heat content of water used/total WH energy use.

(4) Calculation of Stock and late 1980s sales standby losses assumes that all measures used by manufacturers to improve the WH EF affected only standby losses.

(5) Wh.th/hr = watt-hour (thermal) per hour; Btus.th/hr = Btus (thermal) per hour. 
Where total energy used to heat the water $\left(E_{\text {total }}\right)$ is defined as in Equation (2):

$$
E_{\text {total }}=\frac{\text { (Energy content of hot water delivered }+ \text { Standby losses) }}{\text { Recovery efficiency }}
$$

We use these equations to create the characteristics of electric and natural gas water heaters in Table 1, using data from US DOE (1993). Energy factors (EFs) are given either from historic data (Hanford et al. 1994) or for the 1990 standards. These energy factors are used with the above equations to calculate $s$ landby losses and recovery efficiencies for cases where those parameters are not immediataly available. The calculation of "Stock" and "Late 1980s sales" standby losses assumes that all measures used by manufacturers to improve the water heater EFs affected only standby losses.

\subsection{Water temperature assumptions}

Table 2 describes the end-use temperatures assumed in our calculations. The hot water temperature is the weighted average from a survey of water heater temperatures cited in Bancroft et al. (1991). The cold water temperature represents a rough average across the US and over the year, adopted from data in Labs (1979). These two temperatures and the assumed end-use temperatures imply a certain percentage breakdown of hot and cold water use. These percentage breakdowns are used to calculate hot and cold water use from total water use below.

\subsection{Showers, sinks, and faucets}

Table 3 summarizes usage times and flow rates for showers, baths, and faucets. We disaggregate these uses into flow and filling uses because the standards have different effects on them. Flow rate standards affect only the flow portion of the water use. Filling water uses are not affected by these flow rate standards. Flow assumptions for these enduses were created after reviewing the available literature (Bancroft et al. 1991, Kempton 1984, Perlman 1987, Rohles Jr. and Konz 1981, Taylor et al. 1991, Thrasher et al. 1990). We rely most heavily on Brown and Caldwell (1984), which has the most careful and comprehensive treatment of total water use data (though its treatment of hot and cold water disaggregation is cursory at best).

Flow rates for existing showerheads (and faucets) are 3.4 gallons per minute, which is approximately the flow rate found by Brown and Caldwell (1984) and Warwick (1993). The EPACT standards reduce flow rates to 2.5 gallons per minute. Shower usage is assumed to be 5 minutes per person per day ( 2.67 persons per household), which is again based on Brown and Caldwell (1984), and is on the high end of estimates from Rohles et al. (1981) Faucet filling is always assumed to be equal to base case flow for bathrooms, kitchens, and laundry faucets, respectively (filling is not affected by standards).

For homes without dishwashers, we account for the increase in faucet usage associated with handwashing of dishes. We assume that the amount of hot water used for the dishwasher is also used for handwashing, with the added cold water used to bring the temperature of this additional water to 105 degrees $\mathrm{F}$ for both flow and filling components of hand dishwashing. This additional water use is split 50:50 between filling and flow for Pre-1994 households. For Post-1993 households, the flow part of the additional use is reduced to reflect the 1994 EPACT flow standards. Table 4 shows the results of the calculations, weighted by the fraction of homes with and without dishwashers. 
Table 2: Water temperature assumptions and implied hot/cold water use breakdowns

\begin{tabular}{|c|c|c|c|c|}
\hline & Vintage & $\begin{array}{c}\text { Usage } \\
\text { temperature } \\
\text { degrees } F\end{array}$ & \% hot & \% cold \\
\hline $\begin{array}{l}\text { Sink filling } \\
\text { Faucet flow } \\
\text { Bath filling } \\
\text { Showers } \\
\text { Clotheswasher } \\
\text { Dishwasher } \\
\text { Toilets } \\
\text { Yard watering/other }\end{array}$ & $\begin{array}{c}\text { Existing } \\
\text { Post-1993 w/standards }\end{array}$ & $\begin{array}{c}105 \\
80 \\
100 \\
105 \\
83 \\
78 \\
139 \\
60 \\
60\end{array}$ & $\begin{array}{c}57 \% \\
25 \% \\
51 \% \\
57 \% \\
29 \% \\
22 \% \\
100 \% \\
0 \% \\
0 \%\end{array}$ & $\begin{array}{c}43 \% \\
75 \% \\
49 \% \\
43 \% \\
71 \% \\
78 \% \\
0 \% \\
100 \% \\
100 \%\end{array}$ \\
\hline $\begin{array}{l}\text { Hot water temperature }= \\
\text { Cold water temperature }= \\
\text { Warm water temperature }=\end{array}$ & & & $\begin{array}{l}139 \\
60 \\
99\end{array}$ & $\begin{array}{l}\text { degrees } F \\
\text { degrees } F\end{array}$ \\
\hline
\end{tabular}

(1) New clothes washers assumed to eliminate warm rinse option. Temperature for clothes washers is a weighted average based on P\&G data, as cited in DOE 1990 p. 3-11.

(2) Temperature for dishwashers set at highest allowable level.

(3) Faucet flow assumed to be $50 \%$ cold and $50 \%$ warm (warm $=50 \%$ cold, $50 \%$ hot).

(4) Hot water temperature is a weighted average from a survey cited in Bancroft et al. (1991).

(5) Cold water temperature represents a rough annual US average adopted from data in Labs (1979).

(6) Warm water temperature assurned to be a simple average of cold and hot water temperatures.

(7) Shower temperature taken from surveys cited in Brown and Caldwell 1984. 


\begin{tabular}{|c|c|c|c|c|c|c|c|c|c|c|}
\hline & & \multicolumn{6}{|c|}{ Flow uses } & \multicolumn{3}{|c|}{ Baths/sink filling } \\
\hline & & $\begin{array}{c}\text { Usage/person } \\
\text { min/day }\end{array}$ & $\begin{array}{c}\text { Usage/HH } \\
\text { min/day }\end{array}$ & $\begin{array}{c}\text { Flow rate } \\
\text { GPM }\end{array}$ & $\begin{array}{c}\text { Total flow } \\
\text { gals/day }\end{array}$ & $\begin{array}{l}\text { Hot flow } \\
\text { gals/day }\end{array}$ & $\begin{array}{l}\text { Cold flow } \\
\text { gals/day }\end{array}$ & $\begin{array}{c}\text { Total } \\
\text { gals/day }\end{array}$ & $\begin{array}{c}\text { Hot filling } \\
\text { gals/day }\end{array}$ & $\begin{array}{c}\text { Cold filling } \\
\text { gals/day }\end{array}$ \\
\hline \multirow{2}{*}{ Showers/baths } & Pre-1994 & 5 & 13 & 3.4 & 45 & 26 & 19 & 19 & 9.5 & 9.2 \\
\hline & Post-1993 & 5 & 13 & 2.5 & 33 & 19 & 14 & 19 & 9.5 & 9.2 \\
\hline \multirow[t]{2}{*}{ Bathroom faucets } & Pre-1994 & & 1.2 & 3.4 & 4.1 & 1.0 & 3.1 & 4.1 & 2.3 & 1.7 \\
\hline & Post-1993 & & 1.2 & 2.5 & 3.0 & 0.8 & 2.3 & 4.1 & 2.3 & 1.7 \\
\hline \multirow{2}{*}{ Kitchen faucets w/DW } & Pre-1994 & & 1.5 & 3.4 & 5.1 & 1.3 & 3.8 & 5.1 & 2.9 & 2.2 \\
\hline & Post-1993 & & 1.5 & 2.5 & 3.8 & 0.9 & 2.8 & 5.1 & 2.9 & 2.2 \\
\hline \multirow[t]{2}{*}{ Laundry faucets } & Pre-1994 & & 0.3 & 3.4 & 1.0 & 0.3 & 0.8 & 1.0 & 0.6 & 0.4 \\
\hline & Post-1993 & & 0.3 & 2.5 & 0.8 & 0.2 & 0.6 & 1.0 & 0.6 & 0.4 \\
\hline \multirow[t]{2}{*}{ All Faucets w/DW } & Pre-1994 & & 3.0 & 3.4 & 10.2 & 2.6 & 7.7 & 10.2 & 5.8 & 4.4 \\
\hline & Post-1993 & & 3.0 & 2.5 & 7.5 & 1.9 & 5.6 & 10.2 & 5.8 & 4.4 \\
\hline \multirow[t]{2}{*}{ Kitchen faucets w/o DW } & Pre-1994 & & 3.4 & 3.4 & 11.6 & 5.0 & 6.6 & 11.6 & 6.6 & 5.0 \\
\hline & Post-1993 & & 3.4 & 2.5 & 8.5 & 3.7 & 4.9 & 11.6 & 6.6 & 5.0 \\
\hline \multirow{2}{*}{ All Faucets w/o DW } & Pre-1994 & & 4.9 & 3.4 & 17 & 6.3 & 10.4 & 17 & 9.6 & 7.2 \\
\hline & Post-1993 & & 4.9 & 2.5 & 12.3 & 4.6 & 7.7 & 17 & 9.6 & 7.2 \\
\hline
\end{tabular}

(1) All hot and cold water breakdowns taken from Table 2 .

All hand standard mandates flow rates of 2.5 gpm starting 1 January 1994.

(2) Base shower flow rates (3.4 gpm) from Brown and Caldwell 1984. EPACT (1990 US average is 2.67 personshousehold).

Shower usage of 5 minutes/capita/day adapted from Brown and Caldwell 1984 (1990 capita per day and 50 galshath) from Brown and Caldwell 1984,

(3) Total water use for baths using assumption

multiplied by 2.67 persons per household.

(4) Base case faucet flow rates assumed to be the same as shower flow rales ( $3.4 \mathrm{gPm})$. EPACT standard mandaces flow rats, $50 \%$ to kitchen, and $10 \%$ to laundry.

Faucet flow usage assumed to be 3 minutes per day per household, with $40 \%$ going to bathroom laucets,

(4) Faucet filling is always assumed to be equal to base case flow for bathrooms, kitchens, and lausdr fo equal 7.47 gals/day, which is equal to the usage

(5) For homes w/o DW in the "Pre-1994" case, additional hot water use for washing dishes is assumed to equal 7.47 gals/day, which is equater for hand dishwashing.

of pre-1994 DWs. The associated cold water usage is calculared assuming a delivered water temperalure of 105 deg F for the additional water for he 3 , 


\subsection{Toilets}

Table 4 also shows usage per household for toilets. This usage is based on an assumption of 4 flushes per person per day (Brown and Caldwell 1984) and 2.67 persons per household. In the base case, toilets use 4.3 gallons per flush. This value represents the weighted average for 1983 from Brown and Caldwell (1984), adjusted assuming that all new toilets installed between 1983 and 1993 use 3.5 gallons per flush. The EPACT standards reduce this for new toilets after January 1, 1994 to 1.6 gallons per flush.

\subsection{Dishwashers and clotheswashers}

Dishwasher and clothes washer water use per cycle are taken from US DOE (1990). Total cycles are taken from a Proctor and Gamble survey as cited in US DOE (1990). Dishwasher standards save only hot water (because dishwashers only use hot water) while clothes washer standards save both hot and cold water.

Table 4 shows the results of these calculations for pre-and post-1994 standard washers and dishwashers on a saturation-weighted basis (all other end-uses [e.g., toilets] are assumed to have a saturation of $100 \%$ ). Saturations for dishwashers, clothes washers, and water heaters are taken from the electronic version of US DOE (1992) Weighted average water use per household associated with clothes washers and dishwashers is higher for Post1993 households than for Pre-1994 homes because of the greater saturations of these appliances in new houses.

\subsection{Other uses}

To estimate the size of the "Yard/other" water use, we subtracted the water usage per household for pre-1994 households for all identified end-uses in Table 4 from the US Geological Service's estimate of total residential water use per household (Solley et al. 1993). This approach assumes that the total water usage per household does not change between 1990 and 1993. We also assume that this residual usage is the same across all house vintages, appliance vintages, and fixture/fitting vintages, and is constant over the forecast period.

\section{FORECASTING METHODOLOGY AND RESULTS}

We create a simple frozen efficiency forecast for both water use and energy use for water heating. We assume that the saturation and efficiency of equipment existing in the base year remain the same until that equipment is replaced. The saturation and efficiency of new equipment installed throughout the forecast remain at the same level as saturations and efficiencies for new devices in the base year. Equipment retires at an exponential rate equal to the inverse of the equipment lifetime.

\subsection{Forecasted number of households}

Table 5 shows the forecast of number of households, taken from US DOE (1994). We disaggregated this forecast into 4 different combinations of house vintages, appliance vintages, and fixture/fitting vintages. We use exponential retirement rates from Koomey et al. (1993) as stated in the Table to estimate for any year the remaining stock of houses associated with each combination of equipment vintages. 


\begin{tabular}{|c|c|c|c|c|c|c|c|c|c|c|c|c|}
\hline & $\begin{array}{c}\text { Home } \\
\text { vintage }\end{array}$ & $\begin{array}{c}\text { Appliance } \\
\text { vintage }\end{array}$ & \begin{tabular}{|c|} 
Fixtures and \\
fittings \\
vintage
\end{tabular} & $\begin{array}{c}\text { Sink filling } \\
\text { gals/day }\end{array}$ & $\begin{array}{c}\text { Faucet flow } \\
\text { gals/day }\end{array}$ & $\begin{array}{c}\text { Bath filling } \\
\text { gals/day }\end{array}$ & $\begin{array}{l}\text { Showers } \\
\text { gals/day }\end{array}$ & $\begin{array}{c}\text { Clotheswasher } \\
\text { gals/day }\end{array}$ & $\begin{array}{c}\text { Dishwasher } \\
\text { gals/day }\end{array}$ & $\begin{array}{c}\text { Toilets } \\
\text { gals/day }\end{array}$ & $\begin{array}{c}\text { YardVother } \\
\text { gals/day }\end{array}$ & $\begin{array}{c}\text { Total } \\
\text { gals/day }\end{array}$ \\
\hline $\begin{array}{l}\text { Baseline } \\
\text { Hot water }\end{array}$ & $\begin{array}{l}\text { Pre-1994 } \\
\text { Post-1993 }\end{array}$ & $\begin{array}{l}\text { All } \\
\text { All }\end{array}$ & $\begin{array}{l}\text { All } \\
\text { All }\end{array}$ & $\begin{array}{l}7.9 \\
6.7\end{array}$ & $\begin{array}{l}4.6 \\
3.4\end{array}$ & $\begin{array}{l}9.5 \\
9.5\end{array}$ & $\begin{array}{l}26.0 \\
26.0\end{array}$ & $\begin{array}{l}8.2 \\
9.8\end{array}$ & $\begin{array}{l}3.4 \\
5.8\end{array}$ & $\begin{array}{l}0.0 \\
0.0\end{array}$ & $\begin{array}{l}0.0 \\
0.0\end{array}$ & $\begin{array}{l}59.5 \\
61.1\end{array}$ \\
\hline Cold water & $\begin{array}{c}\text { Pre-1994 } \\
\text { Post-1993 }\end{array}$ & $\begin{array}{l}\text { All } \\
\text { All }\end{array}$ & $\begin{array}{l}\text { All } \\
\text { All }\end{array}$ & $\begin{array}{l}5.9 \\
5.0\end{array}$ & $\begin{array}{l}9.2 \\
8.3\end{array}$ & $\begin{array}{l}9.2 \\
9.2\end{array}$ & $\begin{array}{l}19.4 \\
19.4\end{array}$ & $\begin{array}{l}20.3 \\
24.2\end{array}$ & $\begin{array}{l}0.0 \\
0.0\end{array}$ & $\begin{array}{l}59.3 \\
59.3\end{array}$ & $\begin{array}{l}86.4 \\
86.4\end{array}$ & $\begin{array}{l}209.7 \\
211.8\end{array}$ \\
\hline \multirow[t]{3}{*}{$\begin{array}{l}\text { Standards case } \\
\text { Hot water }\end{array}$} & Pre-1994 & Post-1993 & Post-1993 & 7.9 & 3.4 & 9.5 & 19.1 & 5.6 & 2.7 & 0.0 & 0.0 & 48.1 \\
\hline & $\begin{array}{l}\text { Pre-1994 } \\
\text { Pre-1994 }\end{array}$ & Post-1993 & Pre-1994 & 7.9 & 4.6 & 9.5 & 26.0 & 5.6 & 2.7 & 0.0 & 0.0 & 56.2 \\
\hline & \begin{tabular}{|c|} 
Pre-1994 \\
Post-1993
\end{tabular} & $\begin{array}{l}\text { Pre-1994 } \\
\text { Post-1993 }\end{array}$ & $\begin{array}{l}\text { Pre-1994 } \\
\text { Post-1993 }\end{array}$ & $\begin{array}{l}7.9 \\
6.7\end{array}$ & 4.6 & 9.5 & 26.0 & 8.2 & 3.4 & 0.0 & 0.0 & 59.5 \\
\hline \multirow{4}{*}{ Cold water } & Post-1993 & Post-1993 & Post-1993 & 6.7 & 2.5 & 9.5 & 19.1 & 6.6 & 4.6 & 0.0 & 0.0 & 49.0 \\
\hline & $\begin{array}{l}\text { Pre-1994 } \\
\text { Pre-1994 }\end{array}$ & $\begin{array}{l}\text { Post-1993 } \\
\text { Post-1993 }\end{array}$ & $\begin{array}{c}\text { Post-1993 } \\
\text { Pre-1994 }\end{array}$ & $\begin{array}{l}5.9 \\
5.9\end{array}$ & 6.7 & $\begin{array}{l}9.2 \\
9.2\end{array}$ & 14.3 & 19.4 & 0.0 & 29.9 & 86.4 & 171.9 \\
\hline & Pre-1994 & $\begin{array}{l}\text { Post-1993 } \\
\text { Pre-1994 }\end{array}$ & $\begin{array}{l}\text { Pre-1994 } \\
\text { Pre-1994 }\end{array}$ & $\begin{array}{l}5.9 \\
5.9\end{array}$ & $\begin{array}{l}9.2 \\
9.2\end{array}$ & $\begin{array}{l}9.2 \\
9.2\end{array}$ & $\begin{array}{l}19.4 \\
19.4\end{array}$ & 19.4 & 0.0 & 59.3 & 86.4 & 208.8 \\
\hline & Post-1993 & $\begin{array}{l}\text { Pre-1994 } \\
\text { Post-1993 }\end{array}$ & Post-1993 & 5.0 & 6.1 & 9.2 & $\begin{array}{l}19.4 \\
14.3\end{array}$ & $\begin{array}{l}20.3 \\
23.2\end{array}$ & $\begin{array}{l}0.0 \\
0.0\end{array}$ & 59.3 & 86.4 & 209.7 \\
\hline
\end{tabular}

for Pre-1994 and Post-1993 homes, respectively. Saturation of DW is 45\% and 77\% for Pre-1994 and Post-1993 (1) Saturation of CW is 76\% and $91 \%$ for Pre-1994 and Post-1993 herived by calculating saturations for homes built 1985-90 (US DOE 1992).

homes, respectively. Source: RECS 1990; Post-1993 saturations dil dishasher owners are assumed to own clotheswashers. Existing homes without DW or CW do not acquire them during the analysis period.

All dishwasher owners are assumed to own clotheswashers. Existing ho an ysis period. Saturations of sink filling, faucets, showers, baths, toilets,

Appliance saturations for Post- 1993 homes also remain constant over the ana average efficiency until replaced by new devices. New devices always

(2) Reference case is frozen efficiency: existi

have same efficiency as new devices in 1990.

(3) Faucet and shower usage from Table 3 .

(4) Hot water use per appliance for pre-1994 CW is $10.72 \mathrm{gals} / \mathrm{day}$; for post-1993 $\mathrm{CW}$. Usage estimates ( $C W$ cycles per year $=380$. DW cycles per year $=229$ )

is $7.47 \mathrm{gals} /$ day; for post-1993 DW is $5.96 \mathrm{gals} /$ day. Source: US DOE

taken from a Proctor and Gamble survey cited in US DOE (1990).

(5) Toilets flushed 4 times per person per day (2.67 persons/household) from Brown and Caldwell 1984. Capacily of aveak 24 gals/capita per day; taken from Brown and Caldwell 1984).

(5) Toilets flushed 4 teeting EPACT standards use $1.6 \mathrm{gals} / \mathrm{fl}$ ush. Toilet water use includes leakage (20\% of the toilets leak 24 gals/capita per day; taken fousehold (from Solley et al 1993 )

while new toilets meeting EPACT standards use 1.6 gals/net wind washing) is calculated as the difference between total US domestic water use per household (from Solley et al

(6) Water use for yard and other uses (e.g. car washing, window washing) is calculat clotheswashers from our bottom-up calculations. We assume in this calculation that overall

and the sum of water use per household for kitchens, bathrooms,

water use per household does not change between 1990 and 1993. 
Table 5: Number of US households by home vintage, appliance vintage, and fixtures/fittings vintage

\begin{tabular}{|c|c|c|c|c|c|c|c|}
\hline & \multirow{2}{*}{$\begin{array}{c}\text { Home } \\
\text { vintage }\end{array}$} & \multirow{2}{*}{$\begin{array}{c}\text { Appliance } \\
\text { vintage }\end{array}$} & \multirow{2}{*}{$\begin{array}{c}\text { Fixtures and } \\
\text { fittings } \\
\text { vintage }\end{array}$} & \multicolumn{4}{|c|}{ Millions of housetiolds } \\
\hline & & & & 1993 & 2000 & 2005 & 2010 \\
\hline \multirow[t]{5}{*}{ Number of bousebolds } & Pre-1994 & Post-1993 & Post-1993 & 0.0 & 23.9 & 35.5 & 43.9 \\
\hline & Pre-1994 & Post-1993 & Pre-1994 & 0.0 & 12.2 & 15.1 & 15.5 \\
\hline & Pre-1994 & Pre-1994 & Pre-1994 & 95.9 & 54.8 & 36.7 & 24.6 \\
\hline & Post-1993 & Post-1993 & Post-1993 & 0.0 & 10.9 & 18.5 & 26.4 \\
\hline & All & All & All & 95.9 & 101.7 & 105.9 & 110.5 \\
\hline \multirow[t]{5}{*}{$\%$ of bouseholds } & Pre-1994 & Post-1993 & Post-1993 & $0 \%$ & $23 \%$ & $34 \%$ & $40 \%$ \\
\hline & Pre-1994 & Post-1993 & Pre-1994 & $0 \%$ & $12 \%$ & $14 \%$ & $14 \%$ \\
\hline & Pre-1994 & Pre-1994 & Pre-1994 & $100 \%$ & $54 \%$ & $35 \%$ & $22 \%$ \\
\hline & Post-199? & Post-1993 & Post-1993 & $0 \%$ & $11 \%$ & $18 \%$ & $24 \%$ \\
\hline & All & All & All & $100 \%$ & $100 \%$ & $100 \%$ & $100 \%$ \\
\hline
\end{tabular}

(1) Baseline household forecast from US DOE (1994).

(2) 1993 households derived assuming a linear absolute annual increase in households between 1992 and 2000.

(3) Lifetimes for clothes washers, dishwashers, and water heaters assumed to be 13 years, based on Hanford et al. (1994). (WH and DW life $=13$ years, $C W$ life $=14$ years. We assume 13 years for all to reduce complexity).

Lifetimes for fittings and fixtures assumed to be 20 years.

(4) Appliances retire faster than fittings and fixtures, so we assume for simplicity that there are no homes with new faucets/SHs and old appliances.

(5) Home retirement rates taken from Koomey et al. (1993) are $0.77 \%$, averaged over all house types. 


\subsection{Baseline and standards case forecasts: water use}

To calculate total water use, we multiply the water usage per household in each vintage bin in a given year by the number of households in each bin. Table 6 shows the resulting hot and cold water usage by end-use for the US as a whole for 1993 and 2010 . The largest end-use by far is "Yard/other" which represents about one-third of total water use in the base case. Next is toilets, followed by showers and clothes washers. Showers, bath filling, and clothes washers are the largest hot water end-uses. Total water savings is largest for toilets, followed by showers and clothes washers.

\subsection{Baseline and standards case forecasts: energy use}

We use the saturations of different water heater fuel types (new and existing), the hot water usage in Table 6, the standby losses and recovery efficiencies from Table 1 , and the equations above to calculate total energy use in the baseline and standards cases. Saturations for water heaters are taken from the electronic version of US DOE (1992) (saturations for new equipment are derived using the saturation of water heaters for homes built 1985-1990). Table 7 shows the results of these calculations. For electric water heating, suowers are the largest end-use, followed by standby losses, bath filling, and clothes washers. For gas and oil water heating, standby losses are the largest end-use followed by showers, bath filling, and clothes washers.

\subsection{Energy savings}

Table 8 shows the savings from the standards by end-use. The 1990 water heater standards only affect standby losses, while the 1994 fixture/fitting, clothes washer, and dishwasher standards affect only flow rates for these end-uses.

For electric water heaters, the flow-related standards save more than twice as much electricity as the 1990 water heater standards. For gas and oil-fired water heaters, the 1990 water heater standards save about $60 \%$ more energy than the flow related standards. Of the flow related standards, showerhead standards save the most, followed by clothes washers and dishwashers. Total savings in site energy terms are about 0.5 quads per year in 2010, while savings in primary energy terms would be about 0.8 quads per year in 2010 (assuming electricity is valued at $11,157 \mathrm{Btus} / \mathrm{kWh}$ ).

\section{FUTURE WORK}

\subsection{Sensitivity analysis/further disaggregation}

This framework would easily allow testing of the sensitivity of the forecast results to changes in different parameters. Water usage varies by house type, number of persons per household, age of occupants, water prices, water rate structures, source of water (public systems or wells), geography, and income levels. In particular, the effect of standards on households with different appliance ownership and water usage patterns could easily be tested within this framework. An examination of extreme cases (exceptionally low or high water use) would also be illuminating. We believe that creating such a sensitivity analysis should await the arrival of more accurate data on water usage patterns and how these patterns vary across the country. 


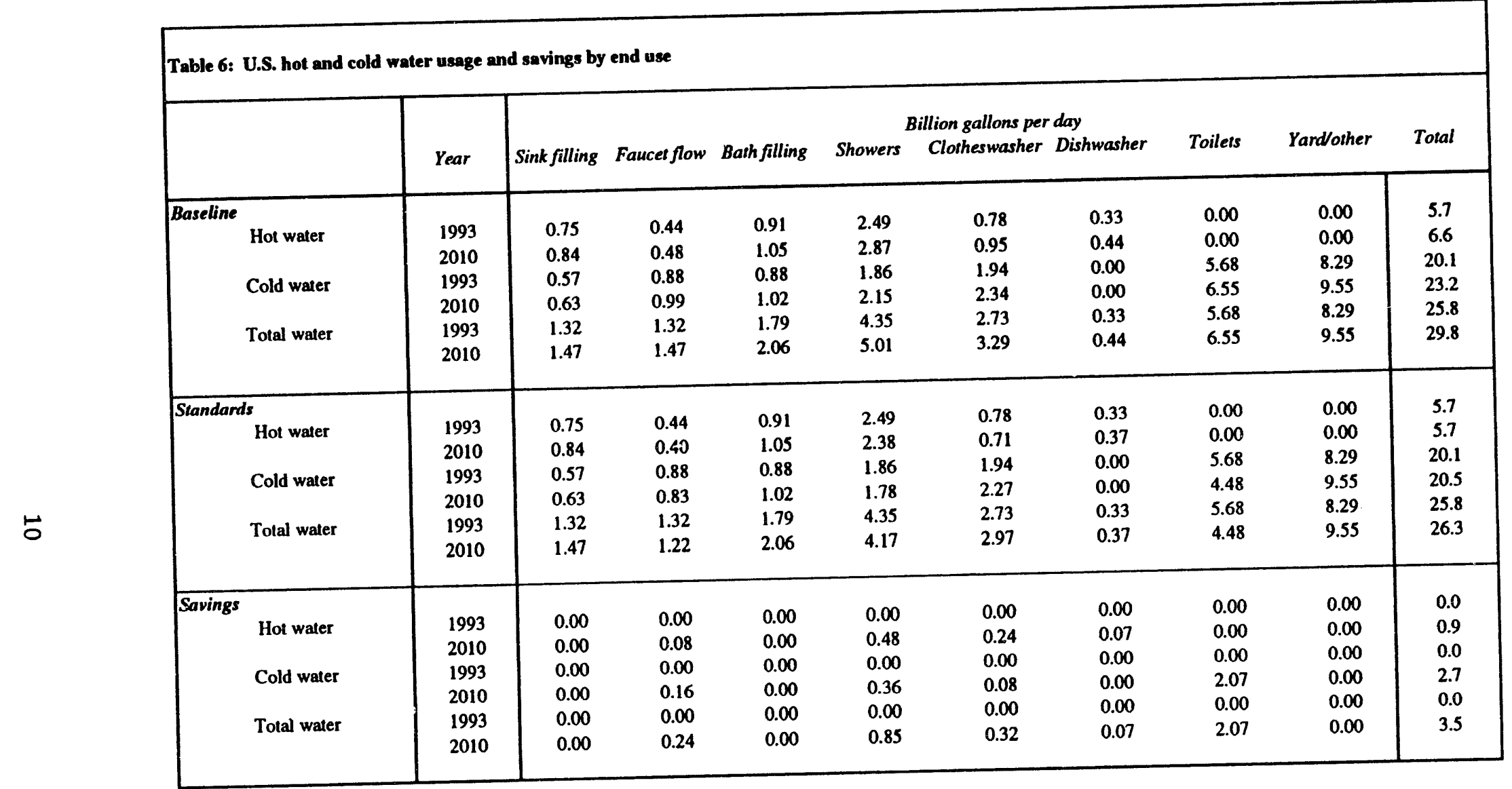
(1) Total usage calculated using weighted average daily per household usage from Table 4 and housing populations frorn Table 5 .
(2) Increase in cold water usage for clotheswasher in standards case caused by elimination of warm rinse cycles and increasing saturation of clotheswashers in new buildings. (3) Toilet water use includes leakage. 


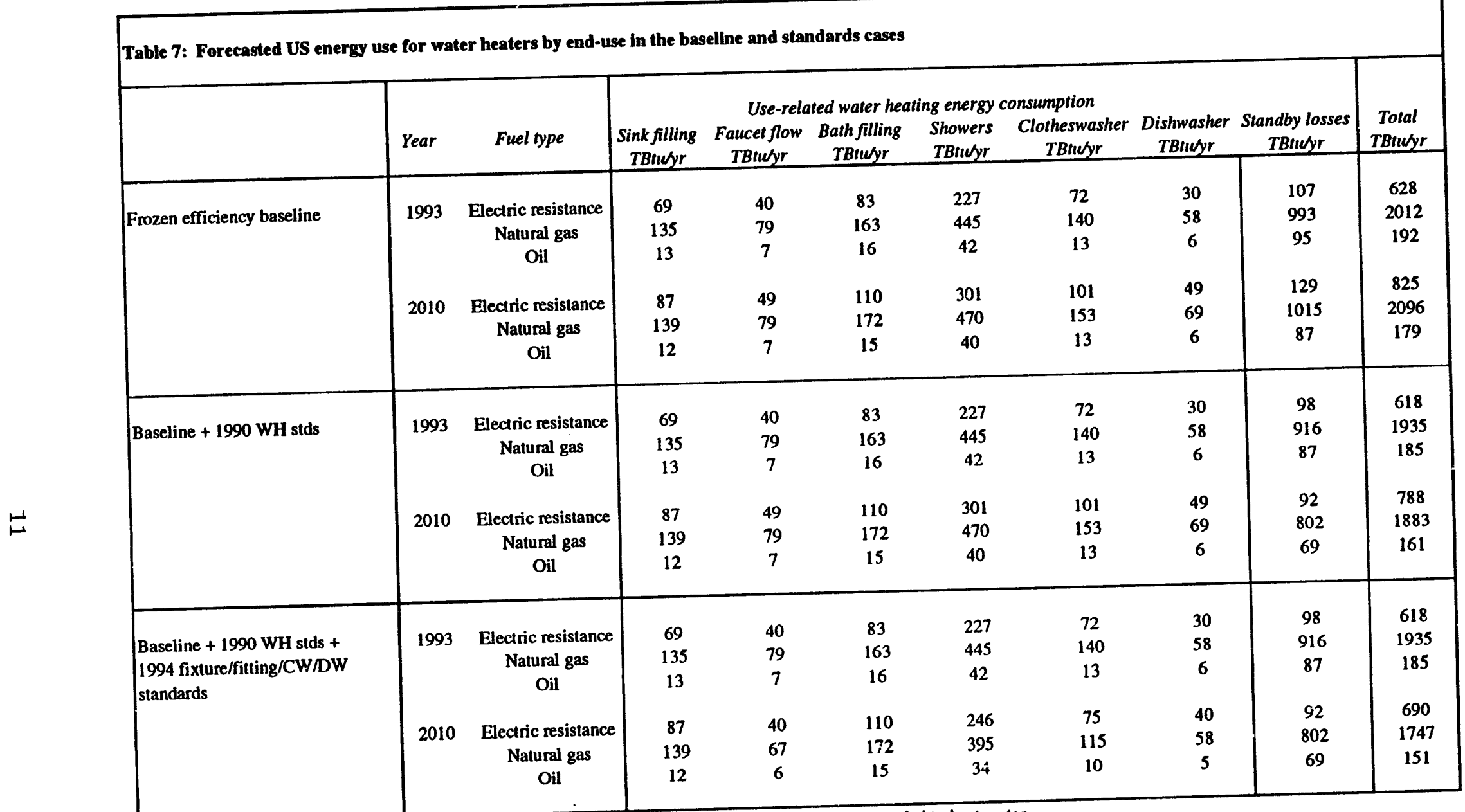

(1) Energy use for clotheswashers and dishwashers does not include motor energy, only the energy needed to heat water.

(2) Electricity measured in site energy at $3412 \mathrm{Btu} / \mathrm{kWh}$.

(3) Saturis

(3) Saturations of water heatig fuel ase are assumed to have the same saluration as new homes in 1990

New homes throughout the analysis period are assumed to have the

(19)

(5) Saturations of electric water hearers: Pre 199 


\begin{tabular}{|c|c|c|c|c|c|c|c|c|c|c|}
\hline & Units & Fuel type & $\begin{array}{c}\text { Sink filling } \\
\text { TBitulyr }\end{array}$ & $\begin{array}{c}\text { Faucet flow } \\
\text { TBtwyr }\end{array}$ & $\begin{array}{c}\text { Use-related wai } \\
\text { Bath filling } \\
\text { TBtwyr } \\
\end{array}$ & $\begin{array}{l}\text { r heating en } \\
\text { Showers } \\
\text { TBtwyr }\end{array}$ & $\begin{array}{l}\text { rgy use } \\
\text { Clotheswasher } \\
\text { TBtwyr }\end{array}$ & $\begin{array}{c}\text { Dishwasher } \\
\text { TBtwyr }\end{array}$ & $\begin{array}{c}\text { Standby losses } \\
\text { TBiwyr }\end{array}$ & $\begin{array}{c}\text { Total } \\
\text { TBtulyr }\end{array}$ \\
\hline 1990 WH stds & $\begin{array}{l}T B t w y r \\
\% \text { of total }\end{array}$ & $\begin{array}{c}\text { Electric resistance } \\
\text { Natural gas } \\
\text { Oil } \\
\text { Electric resistance } \\
\text { Natural gas } \\
\text { Oil }\end{array}$ & $\begin{array}{l}0 \\
0 \\
0 \\
\\
0 \% \\
0 \% \\
0 \%\end{array}$ & $\begin{array}{l}0 \\
0 \\
0 \\
0 \% \\
0 \% \\
0 \%\end{array}$ & $\begin{array}{l}0 \\
0 \\
0 \\
0 \% \\
0 \% \\
0 \%\end{array}$ & $\begin{array}{l}0 \\
0 \\
0 \\
0 \% \\
0 \% \\
0 \%\end{array}$ & $\begin{array}{l}0 \\
0 \\
0 \\
0 \% \\
0 \% \\
0 \%\end{array}$ & $\begin{array}{l}0 \\
0 \\
0 \\
0 \% \\
0 \% \\
0 \%\end{array}$ & \begin{tabular}{c|}
37 \\
214 \\
18 \\
\\
$100 \%$ \\
$100 \%$ \\
$100 \%$
\end{tabular} & $\begin{array}{c}37 \\
214 \\
18 \\
\\
100 \% \\
100 \% \\
100 \%\end{array}$ \\
\hline 1994 fixture/fitting/CW/DW standards & $\begin{array}{c}T B t w y r \\
\% \text { of total }\end{array}$ & \begin{tabular}{|c|} 
Electric resistance \\
Natural gas \\
Oil \\
Electric resistance \\
Natural gas \\
Oil
\end{tabular} & $\begin{array}{l}0 \\
0 \\
0 \\
0 \% \\
0 \% \\
0 \%\end{array}$ & $\begin{array}{c}8 \\
12 \\
1 \\
9 \% \\
9 \% \\
9 \%\end{array}$ & $\begin{array}{l}0 \\
0 \\
0 \\
\\
0 \% \\
0 \% \\
0 \%\end{array}$ & $\begin{array}{c}55 \\
75 \\
6 \\
\\
56 \% \\
55 \% \\
55 \%\end{array}$ & $\begin{array}{c}27 \\
37 \\
3 \\
\\
27 \% \\
28 \% \\
28 \%\end{array}$ & $\begin{array}{c}8 \\
11 \\
1 \\
8 \% \\
8 \% \\
8 \%\end{array}$ & $\begin{array}{l}0 \\
0 \\
0 \\
\\
0 \% \\
0 \% \\
0 \%\end{array}$ & $\begin{array}{c}98 \\
136 \\
11 \\
\\
100 \% \\
100 \% \\
100 \%\end{array}$ \\
\hline $\begin{array}{l}1990 \text { WH sids + } 1994 \text { fixture/ } \\
\text { fitting/CW/DW standards }\end{array}$ & $\begin{array}{l}\text { TBtulyr } \\
\text { \% of total }\end{array}$ & $\begin{array}{c}\text { Electric resistance } \\
\text { Natural gas } \\
\text { Oil } \\
\text { Electric resistance } \\
\text { Natural gas } \\
\text { Oil }\end{array}$ & $\begin{array}{l}0 \\
0 \\
0 \\
0 \% \\
0 \% \\
0 \%\end{array}$ & $\begin{array}{c}8 \\
12 \\
1 \\
\\
6 \% \\
4 \% \\
4 \%\end{array}$ & $\begin{array}{l}0 \\
0 \\
0 \\
\\
0 \% \\
0 \% \\
0 \%\end{array}$ & $\begin{array}{c}55 \\
75 \\
6 \\
\\
41 \% \\
21 \% \\
21 \%\end{array}$ & $\begin{array}{c}27 \\
37 \\
3 \\
\\
20 \% \\
11 \% \\
11 \%\end{array}$ & $\begin{array}{c}8 \\
11 \\
1 \\
\\
6 \% \\
3 \% \\
3 \%\end{array}$ & $\begin{array}{c}37 \\
214 \\
18 \\
\\
27 \% \\
61 \% \\
62 \%\end{array}$ & $\begin{array}{c}135 \\
349 \\
29 \\
\\
100 \% \\
100 \% \\
100 \%\end{array}$ \\
\hline
\end{tabular}

(1) Energy use for clotheswashers and dishwashers does not include motor energy, only the energy needed to heat water.

(2) Electricity measured in site energy at 3412 Btu/kWh.

(3) Saturations of water heating fuel assumed to remain constant throughout the analysis period for existing homes (no conversions).

New homes throughout the analysis period are assumed to have the same saturations as new homes in 1993.

(4) $\mathrm{WH}=$ water heating; $\mathrm{CW}=$ clothes washer; $\mathrm{DW}=$ dishwasher. 


\subsection{Energy losses in delivering water to the tap}

We have not accounted for energy losses associated with transporting hot water from the water heater to the tap. It is not certain how large these losses are, but they may be significant. Multi-family buildings with recirculating water systems are totally different than single family dwellings in this regard, and probably should be analyzed separately in the future. More measurements of such effects are needed.

\subsection{Measurement of water use}

It is crucially important that future programs to measure water use take a comprehensive bottom-up perspective like the one in this paper. Measurements of hot water consumption alone are not sufficient. Cold water use, water heater set point, cold water inlet temperature, and usage temperature must also be measured. In addition, the results must be correlated with detailed information on the characteristics of each household (including saturations and efficiencies of water-using devices) because estimates of water use in the aggregate have little meaning. Finally, accurate measurements of actual usage behavior (i.e., number of flushes per day, minutes of faucet on-time) are also crucial to estimating total water use and the potential for water savings.

\subsection{Comparison to other forecasts}

There are several other widely used forecasts of water heater energy use to which the estimates developed here could be compared (Geller and Nadel 1992, Koomey et al. 1993, US DOE 1994). We have not undertaken this comparison for the sake of brevity, but any further work using this framework should do so. The documentation for these forecasts typically does not include the detailed information needed to make such a comparison, but this information can often be inferred from conversations with the modelers.

\section{5 "Upstream" and "Downstream" issues}

We have ignored energy, economic, and technological issues related to pumping and treatment of water. These issues are complex and have not typically been included in policy studies that focus on direct energy savings from more efficient end-using equipment. They may in some cases be important, especially when conducting cost-benefit analyses in regions where the choice for the local water district may be efficiency policies or adding peak capacity to its water treatment facilities. These issues can also be important for those users not connected to the public water system, because well pumping and septic tanks are substantially affected by changes in total water usage.

\subsection{Enforcement of standards}

If low-flow devices do not deliver equivalent service, then customer satisfaction may lead to circumvention of regulations or changes in usage patterns (i.e., longer showers). We have assumed in this analysis that the low flow devices work exactly as advertised $100 \%$ of the time, and that they do not affect usage behavior. To improve the accuracy of the forecasts, we need data on whether this assumption is even roughly correct.

\section{CONCLUSIONS}

This paper describes a detailed end-use breakdown of hot and cold water use, and uses this breakdown to estimate the effects of recent appliance and fixture/fitting standards on water use and energy use. Such a detailed and comprehensive breakdown is essential for truly 
understanding the water heating end-use. Previous efforts at measurement have generally been inadequate or incomplete, and we hope that this attempt to systematize the various data will serve as a model for future measurements and analysis.

Forecasted water savings from the EPACT standards are largest for toilets, followed by showers, clothes washers, and dishwashers. Hot water savings are greatest for showers and clothes washers, followed by faucets and dishwashers. Forecasted standby loss energy savings from the 1990 electric water heater standards are only about one third as large as electricity savings associated with the EPACT 1994 flow standards. For natural gas water heaters the situation is reversed, with standby loss energy savings from the 1990 gas water heater standards being about $60 \%$ larger in magnitude than gas savings associated with the EPACT 1994 flow standards. Overall primary energy savings associated with current standards affecting water heaters and hot water use are projected to be about 0.8 quadrillion Btus/year by 2010 .

\section{ACKNOWLEDGEMENTS}

We are grateful to Mark Friedrichs of the US Department of Energy for supporting this work. We are also grateful for the careful reviews of Richard Brown (LBL), Celina Atkinson (LBL), Mary Suttor (Quantum Consulting), and Frances Wood (AES). The work described in this paper was supported by the Office of Energy Efficiency and Alternative Fuels Policy, Office of Policy of the U.S. Department of Energy under Contract Number DE-AC03-76SF00098.

\section{REFERENCES}

Bancroft, Brady, Michael Shepard, Amory B. Lovins, Robert C. Bishop, Henry G. Patton, Linda Baynham, John Wilson, and James Johnson. 1991. The State of the Art: Water Heating. Competitek. October.

Brown and Caldwell. 1984. Residential Water Conservation Projects: Summary Report. US Department of Housing and Urban Development. June.

Geller, Howard S., and Steven M. Nadel. 1992. "Consensus National Efficiency Standards for Lamps, Motors, Showerheads and Faucets, and Commercial HVAC Equipment". Presented at ACEEE 1992 Summer Study on Energy Efficiency in Buildings in Asilomar, CA. Published by American Council for an Energy Efficiency Economy.

Hanford, James W., Jonathan G. Koomey, Lisa E. Stewart, Matthew E. Lecar, Francis X. Johnson, and Roland J. Hwang. 1994. Baseline Data for the Residential Sector and Development of a Residential Forecasting Database. Lawrence Berkeley Laboratory. LBL-33717. April.

Kempton, Willet. 1984. "Residential Hot Water: A Behaviorally-Driven System." In Proceedings of the 1984 ACEEE Summer Study on Energy Efficiency in Buildings. Santa Cruz, CA. American Council for an Energy Efficient Economy.

Koomey, Jonathan, Francis X. Johnson, James E. McMahon, Mary Orland, Mark Levine, Peter Chan, and Florentin Krause. 1993. An Assessment of Future Energy Use and Carbon Emissions from U.S. Residences. Lawrence Berkeley Laboratory. LBL32183. December.

Labs, Kenneth. 1979. "Underground Building Climate". Solar Age. October. p. 44. 
Perlman, Maier. 1987. "Residential Water Heating: Low-Tech and High-Tech Alternatives". Energy Auditor and Retrofitter. January/February. p. 25.

Rohles Jr., Frederick H. , and Stephan A. Konz. 1981. Showering Behavior: Implications for Water and Energy Conservation. Institute for Environmental Research, Kansas State University. 81-02. April.

Solley, Wayne B., Robert R. Pierce, and Howard A. Perlman. 1993. Estimated Use of Water in the United States in 1990. US Geological Service (USGS). Circular 1081.

Taylor, M. E., K.G. Ritland, and R. G. Pratt. 1991. Hot Water Electric Energy Use in Single-Family Residences in the Pacific Northwest: Regional End-Use Metering Project. Office of Energy Resources, Bonneville Power Administration. DOE/BP13795-27. September.

Thrasher, William H., D. W. DeWerth, and B. R. Becker. 1990. Comparison of Collected and Compiled Existing Data on Service Hot Water Use Patterns in Residential and Commercial Establishments. ASHRAE. Research Project No. 600-RP. August 8.

US DOE, U.S. Department of Energy. 1990. Technical Support Document: Energy Conservation Standards for Consumer Products: Dishwashers, Clothes Washers, and Clothes Dryers. U.S. Department of Energy, Assistant Secretary, Conservation and Renewable Energy, Building Equipment Division. DOE/CE-0299P. December.

US DOE, U.S. Department of Energy. 1992. Residential Energy Consumption Survey: Housing Characteristics 1990. EIA, Energy Information Administration. DOE/EIA-0314(90). May.

US DOE, U.S. Department of Energy. 1993. Technical Support Document: Energy Conservation Standards for Consumer Products: Room Air Conditioners, Water Heaters, Direct Heating Equipment, Mobile Home Furnaces, Kitchen Ranges and Ovens, Pool Heaters, Fluorescent Lamp Ballasts, and Television Sets. U.S. Department of Energy, Assistant Secretary, Energy Efficiency and Renewable Energy, Building Equipment Division. Volume 3: Water Heaters, Pool Heaters, Direct Heating Equipment, Mobile Home Furnaces; DOE/EE-0009. November.

US DOE, U.S. Department of Energy. 1994. Annual Energy Outiook, with Projections to 2010. Energy Information Administration. DOE/EIA-0383(94). January.

Warwick, W. M. 1993. Energy Savings from Energy-Efficient Showerheads: REMP Case Study Results, Proposed Evaluation Algorithm, and Program Design Implications. Prepared for the Bonneville Power Administration by Pacific Northwest Laboratory. September. 

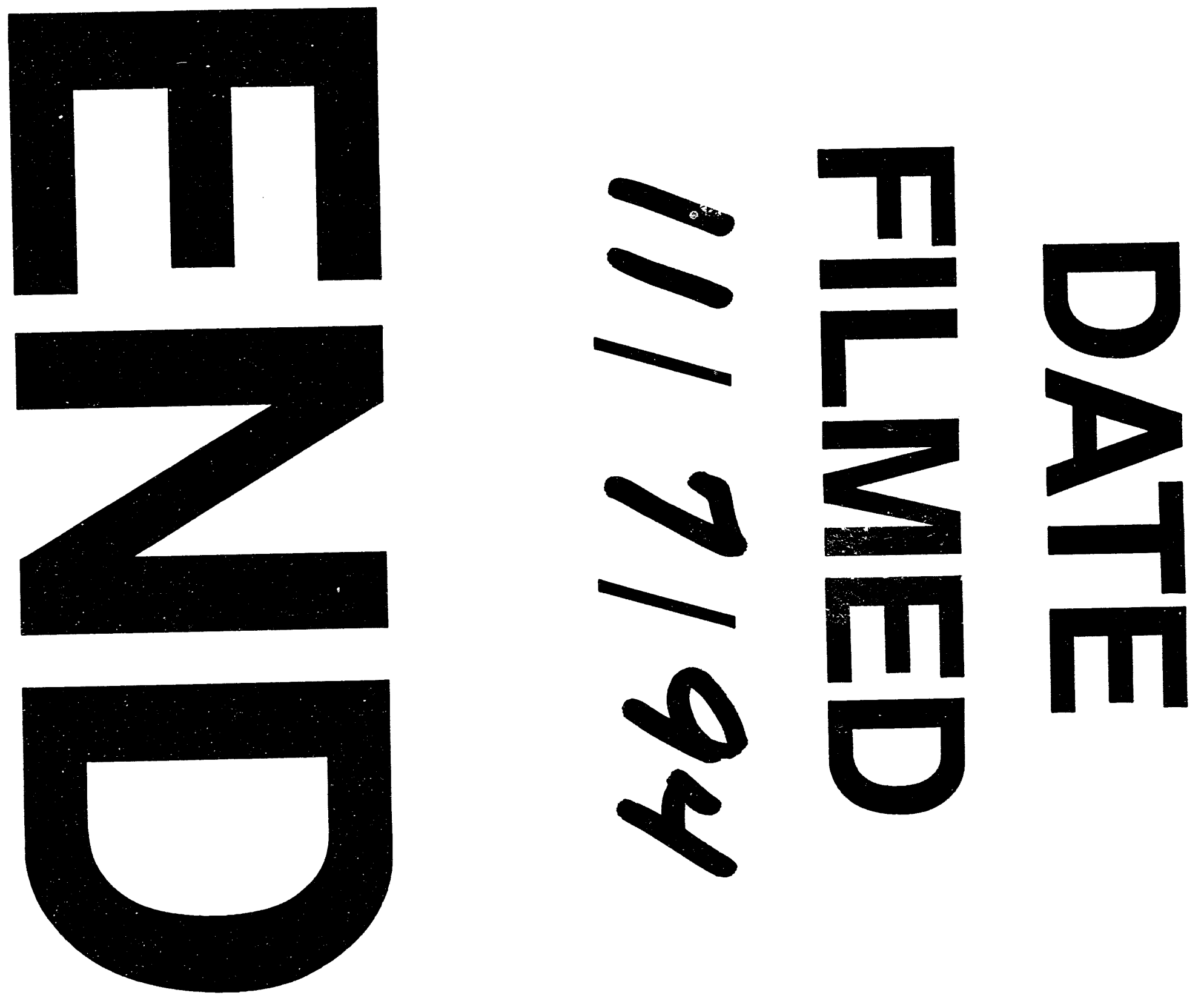


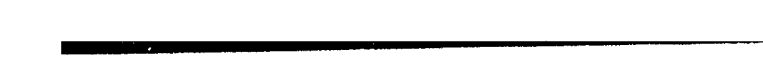

